Journal of Agricultural Sciences
(Tarim Bilimleri Dergisi)

\title{
Screening of Wild Strawberry Germplasm for Iron-deficiency Tolerance Under Hydroponic Conditions
}

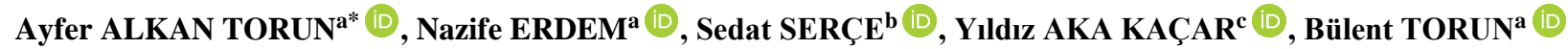 \\ ${ }^{a}$ Department of Soil Science and Plant Nutrition, Faculty of Agriculture, Çukurova University, Adana, TURKEY \\ ${ }^{b}$ Department of Agricultural Genetic Engineering, Faculty of Agricultural Sciences and Technologies, Niğde Ömer Halisdemir University, Niğde, TURKEY \\ ${ }^{c}$ Department of Horticulture, Faculty of Agriculture, Çukurova University, Adana, TURKEY
}

ARTICLE INFO

Research Article

Corresponding Author: Ayfer ALKAN TORUN, E-mail: atorun@ @u.edu.tr

Received: 18 January 2021/ Revised: 07 April 2021 / Accepted: 08 April 2021 / Online: 25 March 2022

\section{ABSTRACT}

Cultivated strawberry has been developed from hybridization between Fragaria chiloensis and $F$. virginiana. The progenitor species exhibit significant genetic diversity. Growth attributes of progenitor species and their responses to several stress factors have been studied. However, irondeficiency tolerance (FeDT) of different species have merely been tested under hydroponic conditions. This study evaluated FeDT of 23 genotypes belonging to super-seed collection under hydroponic conditions. Two genotypes (one Fe-deficiency tolerant and one sensitive) were selected from screening experiment and their physiological and morphological mechanisms playing role in FeDT were determined. Plant parameters associated with FeDT, i.e., pH of the growth medium, root Fe reductase activity, total and active Fe concentration of shoot were recorded. The Feefficiency of strawberry subspecies varied between $51 \%$ and $98 \%$. Fe efficiency values also varied among subspecies. AukeLake and RCP37 belonging to $F$. chiloensis were highly resistant and sensitive to $\mathrm{Fe}-$ deficiency, respectively based on $\mathrm{Fe}$ efficiency values. A highly significant relationship was observed between Fe concentration and FeDT of the genotypes. Acidification of nutrient solution and root Fe reductase activity were closely related to high shoot iron concentration. Our findings indicated existence of a close relationship between root uptake and root to shoot translocation of $\mathrm{Fe}$, which ultimately contribute greatly to FeDT among tested strawberry genotypes.

Keywords: Fe-deficiency, Tolerance, Fe reductase, Genetic resources, Genotype, Gensitivity, Strawberry, Physiological responses

(C) Ankara University, Faculty of Agriculture

\section{Introduction}

Iron $(\mathrm{Fe})$ deficiency is a common nutritional problem in calcareous and alkaline soils of the Mediterranean basin, where horticultural crops are frequently cultivated (Álvarez-Fernández et al. 2006). Fe deficiency in soils and crops has been reported from various regions of Europe, including Spain (Sanz et al. 1992; Pastor et al. 2002), Greece (Tagliavini et al. 2000) and France (Ollat et al. 2003). Likewise, Turkish soils located in the Mediterranean basin are highly calcareous with $74 \%$ of the area containing $>1 \%$ calcium carbonate $\left(\mathrm{CaCO}_{3}\right)$ (Eyupoglu 1999). Despite high total $\mathrm{Fe}$ content in agricultural soils, several physicochemical factors such as high $\mathrm{pH}, \mathrm{CaCO}_{3}$ and clay content, low moisture, organic matter and soil temperature reduce Fe availability for plants (Tagliavini \& Rombola 2001; Marschner 2011). Low Fe availability causes significant yield and quality reduction of fruits, vegetables and grain crops (Hansen et al. 2006; Rombola \& Tagliavini 2006; Álvarez-Fernández 2011).

Various plant species respond differently to Fe deficiency in soils (Vose 1982; Awad et al. 1994; Tagliavini \& Rombola 2001; Chen et al. 2018). Cultivated strawberries, Fragaria $\times$ ananassa Duch., are among the most sensitive species to Fedeficiency (Álvarez-Fernández et al. 2006; Pestana et al. 2011; Alkan Torun et al. 2013, 2014). Several studies have reported varied response of large number of strawberry cultivars to Fe deficiency in different growth mediums (Kafkas et al. 2007; Alkan Torun et al. 2013, 2014; Gama et al. 2016).

Strawberry is one of the most popular summer fruits. Strawberry fruits have unique, highly desirable taste and flavor that influence consumer preferences (Gundogdu et al. 2020). Cultivated strawberry has been originated from hybridization between F. chiloensis (L.) Mill. and F. virginiana Mill. Since that time, a few native clones have been used by the breeders; thus, cultivated strawberries have a narrow genetic base. Since parental species come from a wide geographical region and exhibit great genetic diversity, extended efforts have been made to sample (Hancock et al. 2001a) characterize (Hancock et al. 2001b; Hancock et al. 2003; Hancock et al. 2004), maintain and finally utilize (Hancock et al. 2002, Hancock et al. 2005) the native clones of $F$. virginiana and $F$. chiloensis (Hancock et al. 2001c; Hancock et al. 2010). A super core collection of native clones has been tested across several environments for horticultural attributes (Hancock et al. 2001c). Indeed, cultivated strawberry has been developed 
by crossing the superior clones (Luby et al. 2008; Hancock et al. 2010). The response of super core collection to various biotic and abiotic stress factors have been thoroughly investigated (Serce \& Hancock 2002; Serce et al. 2002; Serce \& Hancock 2005; Lewers 2007). However, responses of the elite native clones to limiting plant nutrients merely been tested.

The objective of this study was to investigate the physiological responses of 23 strawberry genotypes of super core collection, belonging to $F$. chiloensis and $F$. virginiana subspecies to Fe deficiency under hydroponic conditions. Plants derived from the shoot-tip culture were grown in the nutrient solution with sufficient or deficit-Fe supply until the appearance of Fe chlorosis symptoms in young leaves. Changes in chlorophyll density (SPAD), shoot dry matter and concentration of total Fe in the shoot were determined to elucidate the differential responses of the genotypes to the Fe deficiency. Based on the genotypic response, the most sensitive and resistant genotypes were selected and their morphological and physiological mechanisms playing role in Fe-deficiency tolerance were investigated. The result will help breeders to improve Fe-deficiency tolerance of strawberry in the future studies.

\section{Material and Methods}

\subsection{Plant material}

Total 23 wild strawberry genotypes belonging to $F$. chiloensis and $F$. virginiana subspecies (Hancock et al. 2010) were used as plant material in the study. The subspecies and their genotypes $(n=23)$ are listed in Table 1 . A second experiment was conducted with one susceptible and one resistant genotypes selected from these 23 genotypes.

Table 1- List of Fragaria chiloensis and Fragaria virginiana sub-species and genotypes tested for iron-deficiency tolerance under hydroponic conditions

\begin{tabular}{|c|c|c|c|c|}
\hline No. & Subspecies/genotype & & PI Number & Origin \\
\hline \multicolumn{5}{|c|}{ F. chiloensis ssp. pacifica } \\
\hline 1 & RCP 37 & & 551445 & California \\
\hline 2 & WLH (Westport Light House-8) & & 551453 & Washington \\
\hline 3 & BSP 14 & & 551459 & Oregon \\
\hline 4 & Pigeon Point (CA 1367) & & 551728 & California \\
\hline 5 & Auke Lake (CFRA 368) & & 551735 & Alaska \\
\hline 6 & CFRA 1267 & & 612488 & British Columbia \\
\hline 7 & HM 1 (CFRA 1691) & & 612489 & Oregon \\
\hline 8 & Scotts Creek (CFRA 1692) & & 612490 & California \\
\hline \multicolumn{5}{|c|}{ F. chiloensis f. chiloensis } \\
\hline 9 & Darrow 72 (CFRA 24) & & 236579 & Chile \\
\hline 10 & CA 1541 & & 551736 & Peru \\
\hline 11 & 2 BRA 1A (CFRA 1075) & & 612316 & Chile \\
\hline 12 & $\mathrm{NAH}$ & & 612318 & Ecuador \\
\hline \multicolumn{5}{|c|}{ F. chiloensis f. patagonica } \\
\hline \multirow{2}{*}{\multicolumn{5}{|c|}{ F. virginiana ssp. glauca }} \\
\hline & & & & \\
\hline 14 & BT3 (CFRA 1693; CA 1226) & & 612491 & Utah \\
\hline 15 & BH 2 (CFRA 1696; LH 5-1) & & 612494 & South Dakota \\
\hline 16 & LH 50-4 & & 612495 & Montana \\
\hline 17 & RH 43 (CFRA 1698; N8688) & & 612496 & Alaska \\
\hline 18 & LH 30-4 (CFRA 1703) & & 612501 & Montana \\
\hline \multicolumn{5}{|c|}{ F. virginiana ssp. virginiana } \\
\hline 19 & NC $96-35-2$ & & 612323 & Alabama \\
\hline 20 & Eagle 14 (CFRA 1694) & & 612492 & Ontario \\
\hline 21 & JP 95-1 (CFRA 1435) & & 612570 & Florida \\
\hline 22 & RH 23 & & 612498 & Minnesota \\
\hline 23 & NC 95-21-1 & & 612569 & Mississipi \\
\hline
\end{tabular}

\subsection{Plant culture, treatments, tissue sampling and harvest}

Shoot tips from runners of each genotype were cultured in a dedicated nutrient medium (Aka-Kacar \& Cetiner 1992). When sufficient growth was achieved in the fourth subculture, tissues were transferred to main nutrient medium (Murashige \& Skoog 1962). Adaptation of plant material from tissue culture to ambient conditions was performed in an inert perlite medium under greenhouse conditions for three weeks. The resulting plants were then transferred to culture pots filled with $2.7 \mathrm{~L}$ of nutrient solution containing $2.0 \mathrm{mM} \mathrm{Ca}\left(\mathrm{NO}_{3}\right)_{2}, 0.7 \mathrm{mM} \mathrm{K}_{2} \mathrm{SO}_{4}, 0.1 \mathrm{mM} \mathrm{KH} \mathrm{PO}_{4}, 0.1 \mathrm{mM} \mathrm{KCl}, 0.5 \mathrm{mM} \mathrm{MgSO}, 1 \mu \mathrm{M} \mathrm{H}_{3} \mathrm{BO}_{3}, 0.5 \mu \mathrm{M}$ $\mathrm{MnSO}_{4}, 0.5 \mu \mathrm{M} \mathrm{ZnSO}, 0.2 \mu \mathrm{M} \mathrm{CuSO}_{4}$ and $0.01 \mu \mathrm{M}\left(\mathrm{NH}_{4}\right)_{6} \mathrm{Mo}_{7} \mathrm{O}_{24}$. Iron was supplied as Fe-EDTA at deficient $(1 \mu \mathrm{M})$ or sufficient rate $(100 \mu \mathrm{M})($ Cakmak et al. 1987). Each pot contained four plants, and all treatments were repeated thrice. Culture solution was renewed every three days and aerated continuously. Plants were grown for six weeks and harvested as shoots and 
roots when severe symptoms Fe deficiency-induced chlorosis appeared in young leaves. Fresh leaf and root tissue samples were taken for determination of chlorophyll concentration and Fe reductase activity, respectively. Fresh leaf samples were stored at $80{ }^{\circ} \mathrm{C}$ until analysis, whereas the whole shoot samples were dried at $70{ }^{\circ} \mathrm{C}$ until a constant weight was gained.

\subsection{Dry matter production, Fe efficiency and scoring of Fe deficiency symptoms}

Biomass $\left(\mathrm{g} \mathrm{plant}^{-1}\right)$ of the dried shoots was determined on an electronic balance. Iron efficiency was calculated by dividing shoot biomass of Fe-deficit treatment to Fe-sufficient treatment and expressed as percentage. This rate is commonly used in literature to indicate Fe-efficiency of species (Graham 1984). Visual scoring of Fe deficiency-induced chlorosis was evaluated based on the progression of chlorotic area on young leaves using a scale of 0 to 3 where 0 represented "no chlorosis" and 3 "severe chlorosis". The severity of Fe deficiency chlorosis in intact leaves was also measured using a portable chlorophyll meter (SPAD502, Minolta, Japan).

\subsection{Determination of total and active Fe concentration in shoot}

Dried shoots were used for the analysis of total and active Fe concentrations after milling shoot samples to powder in an agate mill. Total Fe concentration was determined according to Ozturk et al. (2006) with slight modifications. Briefly, 125 mg ( \pm 5 ) ground shoot sample was digested in $2 \mathrm{~mL}$ of $30 \% \mathrm{H}_{2} \mathrm{O}_{2}$ and $5 \mathrm{~mL}$ of $65 \% \mathrm{HNO}_{3}$ using a microwave reaction system (Mars Express CEM Corp., Matthews, NC) for 30 min. Following digestion, sample volume was brought to $20 \mathrm{~mL}$ by deionized water and filtered through quantitative filter paper. Iron concentration in extracts was analyzed with an inductively coupled plasma optical emission spectrometer (ICP-OES, Jobin-Yvon, JY138-Ultrace) and the results were checked against a standard reference material (SRM 1547 Peach Leaves, National Institute of Standards and Technology, Gaithersburg, MD, USA).

The concentration of active Fe was also analyzed by ICP-OES following extraction of $100 \mathrm{mg}( \pm 5)$ ground shoot sample in $10 \mathrm{~mL}$ of $1 \mathrm{~N} \mathrm{HCl}$ for $2 \mathrm{~h}$ at $120 \mathrm{rpm}$ (Takkar \& Kaur 1984).

\subsection{Determination of leaf chlorophyll concentration}

Leaf samples of $100 \mathrm{mg}( \pm 5)$ were extracted in $10 \mathrm{~mL}$ of $80 \%$ acetone and centrifuged at 5000 gravity for 15 min. The supernatant was used to determine total chlorophyll concentration according to Lichtenthaler \& Wellburn (1983) following measurement of optical densities of samples at $663 \mathrm{~nm}$.

\subsection{Determination of root Fe-reductase activity}

The root Fe-reductase activity (the reducing capacity of roots for $\mathrm{Fe}^{3+}$ and $\mathrm{Fe}^{2+}$ ) of the genotypes was measured according to Camp et al. (1987).

\subsection{Experimental design and statistical analysis}

The collected data was subjected to Shapiro-Wilk normality test for determining the normality, which indicated a normal distribution. Therefore, original data was used for statistical analysis. Two-way analysis of variance was carried out to determine the significance of data and least significant difference test at 5\% probability was used to separate means where ANOVA indicated significant differences. Principal component analysis with Kaiser normalization was used for easier interpretation and better representation of the results. Data was analyzed using xlstat statistical software.

\section{Results}

Genotypes, Fe treatments and their interactions significantly affected all measured variables during screening experiment (Table 2).

Table 2- Mean square values and significance of SPAD, Shoot biomass and Fe concentration of strawberry genotypes grown with deficit (1 $\mu \mathrm{M} \mathrm{Fe})$ and sufficient $(100 \mu \mathrm{M} \mathrm{Fe}) \mathrm{Fe}$ supply

\begin{tabular}{lcccc}
\hline Source & $d f$ & SPAD & Shoot biomass & Fe concentration \\
\hline Genotype & 22 & $452.5^{*}$ & $117299^{*}$ & $10123^{*}$ \\
Fe treatment & 1 & $25808^{*}$ & $960815^{*}$ & $608250^{*}$ \\
Genotype $\times$ Treatment & 22 & $264.3^{*}$ & $18285^{*}$ & $5075^{*}$ \\
Error & 92 & 6.78 & 4314 & 435.3 \\
\hline
\end{tabular}




\subsection{Severity of Fe deficiency symptoms}

The occurrence of Fe deficiency symptoms (i.e., chlorosis in young leaves) and symptom scores were higher in genotypes sensitive to Fe-deficiency along with reduced SPAD values, shoot biomass and Fe efficiency (Table 3). Genotypes WLH and BSP-14 belonging to $F$. chiloensis ssp. pacifica subspecies had the highest, whereas LH 50-4 and 2BRA 1A belonging to $F$. virginiana ssp. glauca and $F$. chiloensis ssp. chiloensis, respectively observed the lowest symptom scores. Overall, $F$. chiloensis ssp. genotypes (except 2BRA 1A and 2 TAP-4B) expressed more severe symptoms of Fe deficiency compared to F. virginiana ssp. (Table 3).

Table 3- Iron deficiency symptom (chlorosis) scores, SPAD values, shoot biomass, Fe efficiency and total Fe concentration in shoots strawberry genotypes grown under deficit (1 $\mu \mathrm{M} \mathrm{Fe})$ and sufficient (100 $\mu \mathrm{M}$ Fe) Fe supply

\begin{tabular}{|c|c|c|c|c|c|c|c|c|}
\hline \multirow{2}{*}{ Genotype } & \multirow{2}{*}{$\begin{array}{c}\text { Symptom } \\
\text { Score }\end{array}$} & \multicolumn{2}{|c|}{$S P A D$} & \multicolumn{2}{|c|}{$\begin{array}{c}\text { Shoot biomass } \\
\left(\text { mg plant }^{-1}\right)\end{array}$} & \multirow{2}{*}{$\begin{array}{c}\text { Fe efficiency } \\
(\%)\end{array}$} & \multicolumn{2}{|c|}{$\begin{array}{c}\text { Fe concentration } \\
\left(\mathrm{mg} \mathrm{kg}^{-1}\right)\end{array}$} \\
\hline & & $F e_{1}$ & $F e 100$ & $F e_{1}$ & $F e_{100}$ & & $F e_{1}$ & $F e_{100}$ \\
\hline \multicolumn{9}{|c|}{ F. chiloensis ssp. pacifica } \\
\hline RCP 37 & 2.5 & 10.51 & $48.9 \mathrm{~cd}$ & $275 \mathrm{o}-\mathrm{s}$ & $510 \mathrm{~g}-\mathrm{k}$ & 54 & $35 \mathrm{uv}$ & 951 \\
\hline WLH & 3.0 & 10.21 & $53.4 \mathrm{a}-\mathrm{d}$ & 169 rs & $328 \mathrm{~m}-\mathrm{q}$ & 52 & $55 \mathrm{p}-\mathrm{s}$ & $151 \mathrm{~h}$ \\
\hline BSP-14 & 3.0 & $12.0 \mathrm{kl}$ & $53.7 \mathrm{a}-\mathrm{d}$ & $116 \mathrm{~s}$ & 186 qrs & 62 & $30 \mathrm{v}$ & $154 \mathrm{gh}$ \\
\hline Pigeon Point & 2.2 & $12.2 \mathrm{kl}$ & $52.5 \mathrm{bcd}$ & $339 \mathrm{~m}-\mathrm{q}$ & $683 \mathrm{~b}-\mathrm{e}$ & 50 & $33 \mathrm{uv}$ & $107 \mathrm{k}$ \\
\hline Auke Lake & 1.5 & $27.3 \mathrm{i}$ & $51.8 \mathrm{~cd}$ & 319 n-r & $397 \mathrm{j}-\mathrm{p}$ & 80 & $49 \mathrm{q}-\mathrm{t}$ & $170 \mathrm{~g}$ \\
\hline CFRA-1267 & 2.5 & $11.3 \mathrm{kl}$ & $47.7 \mathrm{de}$ & $320 n-q$ & $563 \mathrm{e}-\mathrm{i}$ & 57 & 41 tuv & $121 \mathrm{j}$ \\
\hline HM1 & 2.2 & $13.3 \mathrm{kl}$ & $59.9 \mathrm{a}$ & $3601-p$ & $698 \mathrm{a}-\mathrm{d}$ & 52 & $43 \mathrm{r}-\mathrm{u}$ & $136 \mathrm{i}$ \\
\hline Scotts Creek & 2.5 & $12.3 \mathrm{kl}$ & $52.1 \mathrm{~cd}$ & 475 h-1 & $816 \mathrm{a}$ & 58 & $31 \mathrm{v}$ & 931 \\
\hline \multicolumn{9}{|c|}{ F. chiloensis f. chiloensis } \\
\hline Darrow-72 & 2.2 & $12.9 \mathrm{kl}$ & $48.4 \mathrm{~d}$ & $519 \mathrm{f}-\mathrm{j}$ & $601 \mathrm{c}-\mathrm{h}$ & 86 & $44 \mathrm{q}-\mathrm{u}$ & $104 \mathrm{kl}$ \\
\hline CA-1541 & 2.3 & $12.7 \mathrm{kl}$ & $49.3 \mathrm{~cd}$ & 456 i-m & $759 \mathrm{ab}$ & 60 & 40 tuv & $131 \mathrm{ij}$ \\
\hline 2 BRA $1 \mathrm{~A}$ & 0.5 & $50.9 \mathrm{~cd}$ & $57.3 \mathrm{ab}$ & $462 \mathrm{i}-\mathrm{m}$ & $637 \mathrm{~b}-\mathrm{g}$ & 73 & $59 \mathrm{n}-\mathrm{q}$ & $191 \mathrm{f}$ \\
\hline $\mathrm{NAH}$ & 2.2 & 10.31 & $47.4 \mathrm{de}$ & 480 h-k & $723 \mathrm{abc}$ & 66 & $42 \mathrm{~s}-\mathrm{v}$ & $125 \mathrm{ij}$ \\
\hline \multicolumn{9}{|c|}{ F. chiloensis f. patagonica } \\
\hline 2 TAP-4B & 1.0 & $28.6 \mathrm{i}$ & $50 \mathrm{~cd}$ & $318 \mathrm{n}-\mathrm{r}$ & $563 \mathrm{~d}-\mathrm{i}$ & 56 & $44 \mathrm{q}-\mathrm{u}$ & $205 \mathrm{e}$ \\
\hline \multicolumn{9}{|c|}{ F. virginiana ssp. glauca } \\
\hline BT 3 & 1.2 & $39.0 \mathrm{gh}$ & $42.0 \mathrm{e}-\mathrm{h}$ & $473 \mathrm{~h}-\mathrm{m}$ & $683 b-f$ & 69 & $56 \mathrm{pqr}$ & $189 \mathrm{f}$ \\
\hline BH 2 & 2.0 & $24.8 \mathrm{~d}$ & $47.3 \mathrm{def}$ & 243 p-s & 448 i-n & 54 & $44 \mathrm{q}-\mathrm{u}$ & $196 \mathrm{ef}$ \\
\hline LH 50-4 & 0.5 & $50.2 \mathrm{c}$ & $59.2 \mathrm{a}$ & $3701-p$ & $385 \mathrm{k}-\mathrm{p}$ & 96 & $70 \mathrm{mno}$ & $307 \mathrm{a}$ \\
\hline RH 43 & 1.0 & $46.0 \mathrm{~d}-\mathrm{g}$ & $60.8 \mathrm{a}$ & $276 \mathrm{n}-\mathrm{s}$ & 295 n-s & 94 & $75 \mathrm{mn}$ & $315 \mathrm{a}$ \\
\hline LH 30-4 & 1.5 & $37.2 \mathrm{~h}$ & $53.4 \mathrm{a}-\mathrm{d}$ & $157 \mathrm{~s}$ & 262 o-s & 60 & 56 o-r & $233 \mathrm{~d}$ \\
\hline \multicolumn{9}{|c|}{$F$. virginiana ssp. virginiana } \\
\hline NC 96-35-2 & 1.5 & $40.1 \mathrm{fgh}$ & $55.5 \mathrm{abc}$ & $3701-p$ & $3781-p$ & 98 & $61 n-q$ & $319 \mathrm{a}$ \\
\hline Eagle-14 & 0.7 & $48.6 \mathrm{~d}$ & $57.5 \mathrm{a}$ & $3541-p$ & $3761-p$ & 94 & $70 \mathrm{~m}$ & $249 \mathrm{c}$ \\
\hline RH 23 & 2.0 & $23.9 \mathrm{ij}$ & $48.0 \mathrm{~d}$ & $261 \mathrm{p}-\mathrm{s}$ & 312 n-r & 84 & $63 \mathrm{nqp}$ & 189 ef \\
\hline NC 95-21-1 & 2.0 & $18.2 \mathrm{jk}$ & $50.8 \mathrm{~cd}$ & $216 \mathrm{p}-\mathrm{s}$ & $3631-p$ & 59 & $25 \mathrm{v}$ & $231 \mathrm{~d}$ \\
\hline JP 95-1 & 2.2 & $16.2 \mathrm{k}$ & $50.6 \mathrm{~cd}$ & 202 q-s & 398 i-o & 51 & $54 \mathrm{p}-\mathrm{t}$ & $235 \mathrm{~b}$ \\
\hline$L S D($ alpha $=0.05)$ & & 4.33 & & 106.51 & & & 33.83 & \\
\hline
\end{tabular}

Means sharing different letters within a column statistically differ from each other.

Moreover, Fe deficiency symptom scores were in line with SPAD readings of intact leaves and chlorophyll concentration. The mean SPAD values of the $F$. chiloensis ssp. genotypes (except 2BRA 1A and 2 TAP-4B) were remarkably lower under Fe- 
deficiency compared to $F$. virginiana ssp. genotypes. Lower SPAD values are considered as an indication of higher sensitivity of $F$. virginiana ssp. to Fe-deficiency. As expected, mean SPAD value significantly increased under sufficient-Fe availability, especially in sensitive genotypes to Fe-deficiency. Similar to the differences in sensitivity to Fe-deficiency between subspecies, genotypes of a given subspecies also differed in sensitivity to Fe-deficiency. The differences were highly prominent among the genotypes of $F$. virginiana ssp. virginiana and $F$. chiloensis ssp. chiloensis as indicated by broad differences in SPAD values (i.e., up to 4-5 fold). However, under sufficient-Fe treatment the differences in SPAD values among genotypes were much lower (Table 3).

\subsection{Shoot biomass and iron efficiency}

A great variation (116-519 $\mathrm{mg} \mathrm{plant}^{-1}$ ) was noted for shoot biomass among genotypes (Table 3). Variability in biomass was also similar under Fe-sufficient treatment. The subspecies with the highest and lowest biomass production under Fe-deficiency were $F$. chiloensis ssp. chiloensis and F. chiloensis ssp. pacifica, respectively. These results suggested that, subspecies of $F$. chiloensis were more sensitive to Fe-deficiency than $F$. virginiana. Compared to Fe-deficit conditions, biomass under Fe-sufficient treatment was $77 \%, 42 \%, 77 \%, 36 \%$ and $29 \%$ higher in $F$. chiloensis ssp. pacifica, $F$. chiloensis ssp. chiloensis, $F$. chiloensis ssp. patagonica, $F$. virginiana ssp. glauca and $F$. virginiana ssp. virginiana, respectively. Indeed, Fe-efficiency, an important variable in Fe-deficiency tolerance, was relatively higher (with few exceptions) among genotypes of $F$. virginiana ssp. virginiana and $F$. virginiana ssp. glauca subspecies with mean values of $77 \%$ and $73 \%$, respectively (Table 3 ). The Fe efficiency was markedly lower in F. chiloensis spp., except Auke Lake and Darrow-72 genotypes, which are apparently Fe-efficient. Huge variation in biomass and Fe efficiency can be important traits in breeding programs aiming for Fe deficiency-tolerant and high yielding cultivars.

\subsection{Shoot iron concentration}

Shoot Fe concentration significantly varied among genotypes, especially under Fe-deficit conditions. The mean shoot Fe concentrations under Fe-deficit treatment were $60,55,46,44$ and $39 \mathrm{mg} \mathrm{Fe} \mathrm{kg}^{-1}$ for $F$. virginiana ssp. glauca, $F$. virginiana ssp. virginiana, F. chiloensis f. chiloensis, F. chiloensis f. patagonica and F. chiloensis ssp. pacifica, respectively (Tables 3). Irondeficit treatment severely reduced shoot Fe concentration in all genotypes at variable rates. For example, in NC 95-21-1 Fe concentration was reduced from 231 to $25 \mathrm{mg} \mathrm{kg}^{-1}$ as compared to Darrow-72 from 104 to $44 \mathrm{mg} \mathrm{kg}^{-1}$, corresponding to 9.2 to 2.4 fold of difference in shoot Fe concentration, respectively (Tables 3 ).

The Fe-efficient subspecies and genotypes had higher shoot Fe concentrations than subspecies with lower Fe efficiency (Table 3). This finding indicated the significance of shoot Fe concentration in Fe efficiency of the genotypes under Fe-deficit conditions. Thus, a significant correlation $\left(\mathrm{R}^{2}=0.49, \mathrm{P}<0.001\right)$ between the shoot Fe concentrations of genotypes under Fedeficit treatment was observed.

\subsection{Principal component analysis}

Principal component analysis (PCA) yielded two principal components with eigenvalues greater than one. These two axis explained $80.55 \%$ of the total variation in the data (Table 4). All of the measured variables significantly contributed towards the variability. The genotypes were divided into 2 groups. The first group had similar SPAD values and Fe uptake, which contained 5 genotypes. The second group had genotypes with similar biomass production and contained 7 genotypes. The remaining 11 genotypes had variable values of the measured traits (Figure 1). The PCA did not group the genotypes on subspecies, indicating that genotypes belonging to different subspecies exhibit similarities in the measured traits.

Table 4- Factor loading and variability explained by first two axis of the principal component analysis.

\begin{tabular}{lrr}
\hline Variables & $P C 1$ & $P C 2$ \\
\hline SPADFe- & 0.81 & 0.46 \\
PADFe+ & 0.64 & 0.11 \\
BiomassFe- & -0.36 & 0.91 \\
BiomssFe+ & -0.72 & 0.63 \\
FeFe- & 0.83 & 0.37 \\
FeFe+ & 0.91 & 0.03 \\
Eigenvalue & 3.24 & 1.59 \\
Variability (\%) & 53.97 & 26.58 \\
Cumulative \% & 53.97 & 80.55 \\
\hline
\end{tabular}

$\mathrm{Fe}-$ and $\mathrm{Fe}+$ indicate Fe-deficit and Fe-sufficient treatments, respectively. 


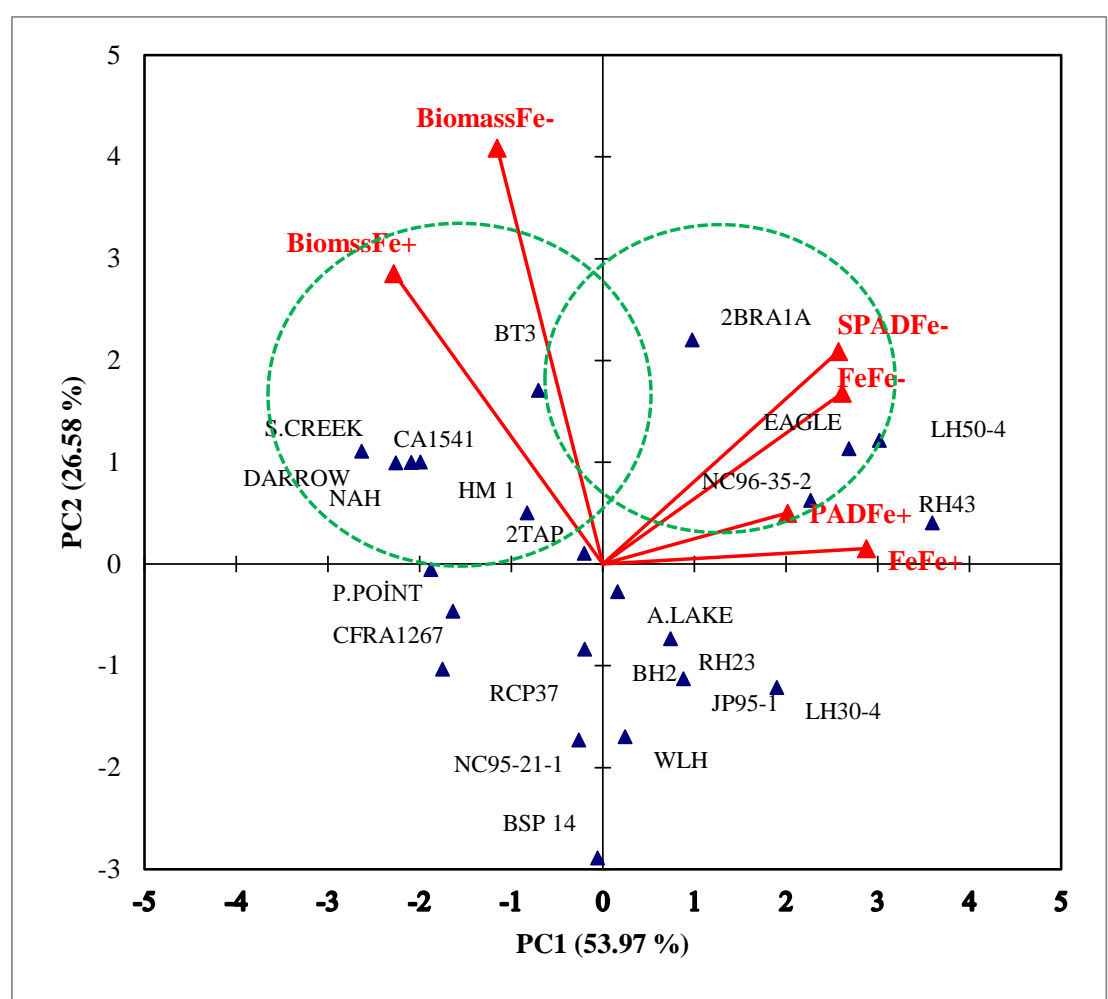

Figure 1- Biplot of first two axis of principal component analysis executed on the biomass, SPAD values and Fe accumulation of 23 strawberry genotypes

\subsection{Important characteristics in iron-deficiency tolerance}

The second set of experiment was conducted by using RCP37 (Fe-inefficient: 54\%) and Auke Lake (Fe-efficient: $80 \%$ ) genotypes of $F$. chiloensis ssp. pacifica subspecies to determine the important characters for Fe-deficiency tolerance. Since strawberry is a strategy-I plant, root Fe reductase activity and rhizosphere acidification are significant factors. Chlorophyll density of leaves (SPAD values), total and active Fe levels were determined. Fe-deficit $(1 \mu \mathrm{M})$ and Fe-sufficient $(100 \mu \mathrm{M})$ treatment significantly $(\mathrm{P}<0.05)$ affected all measured variables (Table 5). Both genotypes showed chlorosis under Fe-deficit supply; however, symptoms were more severe in Fe-inefficient RCP 37 genotype. The SPAD readings and chlorophyll values RCP 37 genotype were 13 and $0.6 \mathrm{mg} \mathrm{g}^{-1}$, while the Fe-efficient Auke Lake had higher values for these variables (19 and $1.2 \mathrm{mg} \mathrm{g}^{-1}$ ) (Table 5). The Fe-efficient genotype produced $837 \mathrm{mg}$ plant $^{-1}$ dry matter under Fe-deficit supply, while Fe-sensitive genotype could only produce about half of this dry matter. However, the dry matter production of both genotypes was higher under sufficient Fe supply (1145 and $510 \mathrm{mg}$ plant $^{-1}$ for Auke Lake and RCP 37, respectively) corresponding to $37 \%$ and $56 \%$ increase compared to Fe-deficit treatment (Table 5; Figure 2). 

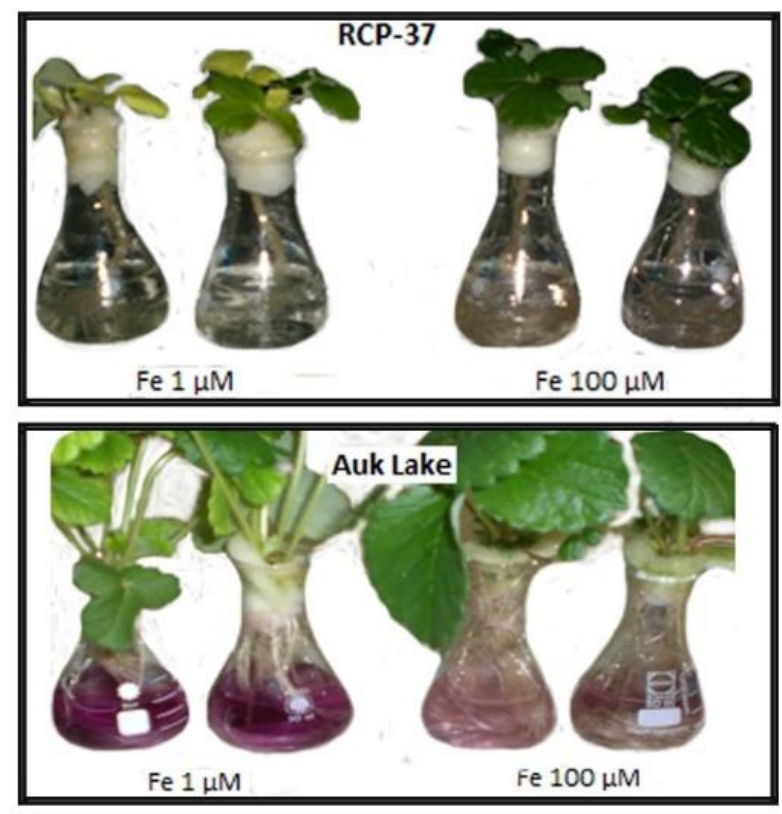

Figure 2- Changes in root Fe-reductase activity of Auke Lake and RCP-37 strawberry genotypes grown under deficit and sufficient Fe supply

Higher production of biomass under deficit and sufficient Fe supply by Auke Lake genotype can be related to its higher root Fe uptake ability (Table 5). Both genotypes maintained a similar pH level (6.3 and 6.4) in the culture solution under sufficient Fe supply. However, Auke Lake reduced the solution pH (4.8) to a higher extent compared to RCP 37 (5.3) under Fe-deficit condition (Table 4). Furthermore, Auke Lake expressed higher root Fe-reductase activity as compared to RCP 37 (8.3 and 6.6 $\mu \mathrm{mol} \mathrm{g}$ root $^{-1} 2 \mathrm{~h}^{-1}$, respectively) under Fe-deficit conditions. Nonetheless, both genotypes had a similar Fe-reductase activity under Fe-sufficient condition (i.e., 1.4-1.0 $\mu \mathrm{mol} \mathrm{g} \mathrm{root}^{-1} 2 \mathrm{~h}^{-1}$ ) (Table 5 and Figure 3). 

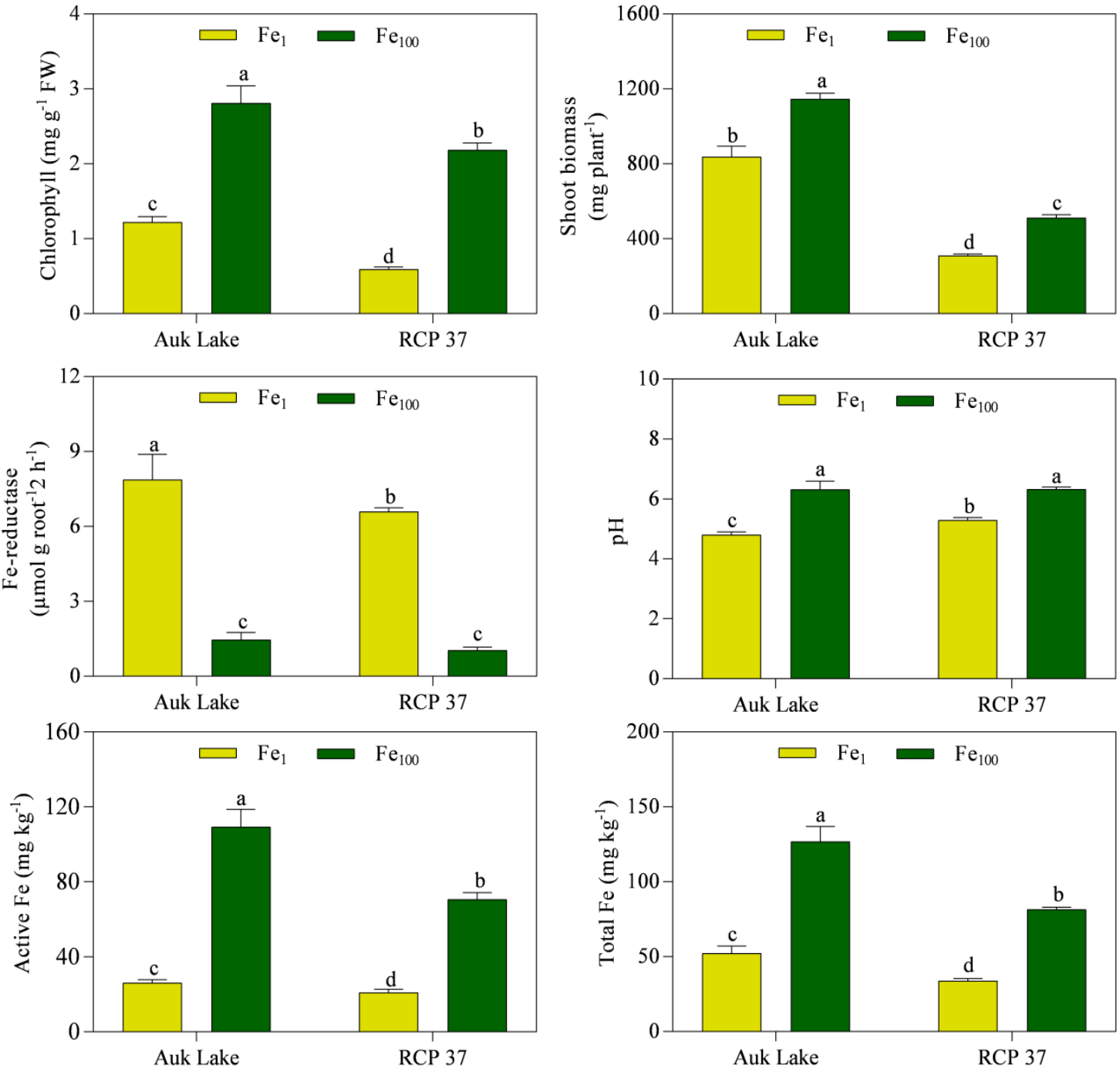

Figure 3- Changes in chlorophyll concentration shoot biomass, nutrient solution pH, root Fe-reductase activity, total and active Fe concentrations in shoots of Auke Lake and RCP 37 strawberry genotypes grown under deficit and sufficient Fe supply

Table 5- Changes in SPAD, chlorophyll concentration, shoot biomass, nutrient solution $\mathrm{pH}$, root Fe-reductase, and total and active Fe concentrations in shoots of Auke Lake and RCP 37 strawberry genotypes under Fe-deficit (1 $\mu \mathrm{M})$ and Fe-sufficient (100 $\mu \mathrm{M}) \mathrm{Fe}$ supply

\begin{tabular}{|c|c|c|c|c|c|c|c|c|}
\hline \multirow{2}{*}{ Variable } & \multicolumn{2}{|c|}{$\mathbf{F e}_{1}$} & \multicolumn{2}{|c|}{$\mathrm{Fe}_{100}$} & \multicolumn{4}{|c|}{ Mean squares and significance } \\
\hline & $\begin{array}{l}\text { Auke } \\
\text { Lake }\end{array}$ & RCP 37 & Auke Lake & RCP 37 & $\begin{array}{c}\text { Genotype } \\
\text { (G) }\end{array}$ & $\begin{array}{c}\text { Fe } \\
\text { Treatment } \\
(\mathbf{T})\end{array}$ & $\mathbf{G} \times \mathbf{T}$ & Error \\
\hline SPAD & $19 \pm 1.5 \mathrm{c}$ & $13 \pm 1.2 \mathrm{~d}$ & $38 \pm 0.7 b$ & $42 \pm 1.7 \mathrm{a}$ & 3.4 & $2275.3^{*}$ & $96.0 *$ & 1.80 \\
\hline Chlorophyll ( $\left.\mathrm{mg} \mathrm{g}^{-1} \mathrm{FW}\right)$ & $1.2 \pm 0.1$ & $0.6 \pm 0.03$ & $2.81 \pm 0.2$ & $2.18 \pm 0.1$ & $1.17 *$ & $7.61 *$ & 0.00 & 0.02 \\
\hline Shoot biomass (mg plant ${ }^{-1}$ ) & $837 \pm 82 c$ & $309 \pm 17 d$ & $1145 \pm 33 a$ & $510 \pm 25 b$ & $1013264 *$ & $194820 *$ & $8587 *$ & 1197 \\
\hline Nutrient solution $\mathrm{pH}$ & $4.8 \pm 0.4 \mathrm{c}$ & $5.3 \pm 0.1 b$ & $6.4 \pm 0.2 \mathrm{a}$ & $6.3 \pm 0.1 \mathrm{a}$ & 0.28 & $6.64 *$ & $0.40 *$ & 0.07 \\
\hline Fe-reductase $\left(\mu \mathrm{mol} g \operatorname{root}^{-1} 2 \mathrm{~h}^{-1}\right)$ & $8.3 \pm 0.9 \mathrm{a}$ & $6.6 \pm 0.1 b$ & $1.4 \pm 0.2 \mathrm{c}$ & $1.0 \pm 0.1 \mathrm{c}$ & $3.91 *$ & $151.4^{*}$ & $1.41 *$ & 0.28 \\
\hline Total Fe $\left(\mathrm{mg} \mathrm{kg}^{-1}\right)$ & $52 \pm 4.8 \mathrm{c}$ & $34 \pm 1.5 \mathrm{~d}$ & $127 \pm 10 \mathrm{a}$ & $82 \pm 1.4 b$ & $3035^{*}$ & $11239 *$ & $534 *$ & 32.3 \\
\hline Active $\mathrm{Fe}\left(\mathrm{mg} \mathrm{kg}^{-1}\right)$ & $26 \pm 1.8 \mathrm{c}$ & $21 \pm 1.9 c$ & $109 \pm 9 a$ & $71 \pm 3 b$ & $1404 *$ & $13377 *$ & $870^{*}$ & 26.4 \\
\hline
\end{tabular}




\section{Discussion}

Different genotypes significantly differed for all measured variables under sufficient and deficit Fe supply. The SPAD values indicating chlorophyll levels of the genotypes and consequently Fe-deficiency tolerance (FeDT) varied among subspecies and genotypes of the same subspecies. SPAD values were less than 20 under Fe deficiency for majority of the strawberry genotypes. Chlorophyll contents increased with Fe application and the SPAD values were generally around 50 under sufficient Fe supply. Gama et al. (2016) reported similar for SPAD values under Fe deficiency in strawberry. Pestana et al. (2012a) compared the responses of carob (Ceratonia siliqua L.) and three-foil lemon (Poncirus trifoliata (L.) Raf) tree rootstocks against Fe deficiency under hydroponic conditions with different Fe levels. Significant reductions in growth and SPAD values were reported for threefoil lemon under Fe-deficit treatment. However, growth and SPAD readings for carob were similar under all Fe treatments.

Retarded plant growth, decreased dry matter, reduced shoot, grain and fruit yields are among the major impacts of Fe chlorosis. Fe deficiency reduced biomass production of all subspecies included in the study compared to sufficient Fe supply (Table 3). In the second experiment, increased dry matter under sufficient Fe supply was $27 \%$ and $36 \%$ for Auke Lake and RCP 37 genotypes, respectively (Table 5). Results revealed that decreased biomass of tested genotypes by Fe deficiency was correlated with symptom scores under Fe deficiency. Similar decreases in yield and yield components of crops caused by Fe-deficiency chlorosis have been reported in various studies (Álvarez-Fernández et al. 2011; Gama et al. 2016). For example, fruit yield in

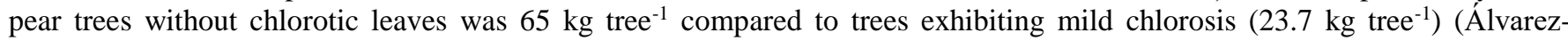
Fernández et al. 2011). Similarly, fruit yield in peach trees with none (SPAD values of 39-43), mild (SPAD values of 24-44) and severe (SPAD values of 18-24) Fe-deficiency chlorosis were 128, 21.8 and $33.8 \mathrm{~kg}^{-1}$ tree ${ }^{-1}$, respectively (Álvarez-Fernández et al. 2011). Consequently, overall decrease in fruit yield in trees with mild chlorosis was about $64 \%$ in pear and $83 \%$ in peach.

In the current study, Fe deficiency caused significant reduction in chlorophyll contents, biomass and leaf Fe concentrations. Average leaf Fe contents of $F$. chiloensis ssp. pacifica genotypes under sufficient and deficit Fe supply were 128 and $39 \mathrm{mg}$ kg 1 , respectively, corresponding to $70 \%$ decrease (Table 3). The decrease in F. chiloensis ssp. chiloensis, F. chiloensis ssp. patagonica, $F$. virginiana ssp. glauca and $F$. virginiana ssp. virginiana subspecies were 67, 79, 76 and 77\%, respectively. Similar decrease in Fe concentration has also been reported by Jelali et al. (2010) in pea and Gama et al. (2016) in strawberry. Plant tissue Fe concentration of Merveille de Kelvedon and Lincoln pea cultivars was 15.0 and $17.4 \mathrm{mg} \mathrm{kg}^{-1}$ under sufficient Fe supply compared to 9.7 and $10.4 \mathrm{mg} \mathrm{kg}^{-1}$ under deficient Fe. However, the lowest Fe concentration was observed in plants receiving lime treatments where Fe concentration was reduced by $35.3 \%$ in Merveille de Kelvedon and 40.4\% in Lincon compared to the non-limed treatment (Jelali et al. 2010).

Our results indicated positive correlation between Fe efficiency values and leaf Fe concentrations under Fe deficiency. This finding indicates the existence of variation in the uptake, transport and/or utilization of Fe in strawberry subspecies and genotypes. Jelali et al. (2010) also reported variation in Fe efficiency in pea grown under sufficient and deficit Fe supply.

Growth medium acidification mediated by $\mathrm{H}^{+}$-ATPase, Fe-reductase and release of organic acids from roots are specified as significant mechanisms for Fe uptake conferring FeDT (Han et al. 1998; Vizzotto et al. 1999; Jelali et al. 2010; Pestana et al. 2012b; Gama et al. 2016). Proton release level and ability of growth medium acidification substantially varied among strawberry genotypes tested in the current study. The initial nutrient solution $\mathrm{pH}$ values (6.3-6.4) decreased to 4.8 in Auke Lake and 5.3 in RCP 37 genotype under deficit Fe supply (Table 5; Figure 2). These results are in line with Pestana et al. (2012b) where similar decrease in solution $\mathrm{pH}$ was reported in strawberry under deficit Fe supply. Similar findings were also reported for pea cultivars under Fe deficiency (Jelali et al. 2010). Both pea cultivars acidified the growth medium under Fe-deficit conditions and the greatest decline ( $\mathrm{pH}$ 3.35) was observed in Marveille de Kelvedon cultivar. In a study with different quince and pear genotypes grown in a calcareous soil, rhizosphere $\mathrm{pH}$ values of quince genotypes were higher than pear genotypes (Tagliavini et al. 1995). Fe-efficient Malus $\times$ iaojinensis (apple) genotype decreased rhizosphere $\mathrm{pH}$ by 2 units in calcareous soils under Fe deficiency (Han et al. 1998, 1994). Mengel \& Malissovas (1982) investigated $\mathrm{H}^{+}$release from the roots of Huxel and Faber vine cultivars into the nutrient solution and reported severe chlorosis in Huxel grown on calcareous soils. Faber was Fe deficiency tolerant as it released $406 \mu \mathrm{mol} \mathrm{H}{ }^{+}$per plant from the roots in 12 hours, whereas Huxel released only $173 \mu \mathrm{mol}_{12} \mathrm{~h}^{-1} \mathrm{plant}^{-1}\left(\mathrm{Mengel}_{\mathrm{C}}\right.$ Malissovas 1982). Our results suggested that variation in proton release capacity of strawberry genotypes under Fe-limiting conditions can be exploited as a selective trait in breeding new cultivars with higher FeDT.

The $\mathrm{Fe}^{+3}$ reduction ability of genotypes into $\mathrm{Fe}^{+2}$ through Fe-reductase enzyme activity of roots is another significant character for FeDT. The Fe-reductase enzyme activity in the Fe-efficient genotype was induced to a higher extent compared to the Fe-inefficient genotype (Table 5; Figure 2). Higher Fe-reductase activities have been reported for various Fe-efficient plant species. Pear rootstock Cydonia oblonga is classified as Fe-sensitive and Pyrus communis as Fe-resistant. Fe-reductase activities of pears under Fe deficiency increased with Fe application, though a similar increase was not occurred in quince (Tagliavini et al. 1995). The effect of $\mathrm{HCO}_{3}{ }^{-}$on Fe-reductase activity varied between quince and pear and caused a higher decrease in quince compared to the pear. Variation in Fe-reductase activity was related to the higher decreases in the rhizosphere pH of Fe-resistant $P$. communis than C. oblonga (Tagliavini et al. 1995). In contrast, Alcantara et al. (2000) reported that Fe-reductase activity was not always related to Fe-chlorosis. These reports indicate that the mechanisms involved in FeDT could be mediated by multiple environmental factors, including but not limited to Fe availability in the growth media. 


\section{Conclusions}

The results of the present study found substantial variation in Fe efficiency (ability to grow under limited Fe supply) among and within Fragaria chiloensis and Fragaria virginiana strawberry subspecies and genotypes. Proton (H+) release capacity and Fereductase enzyme activity in the roots, and total and active Fe concentration in shoots were found to be important in resistance to iron deficiency for strawberry genotypes. The results of the current study can be used to improve iron deficiency tolerance in cultivated strawberry.

\section{Acknowledgements}

This work was supported by the Scientific and Technological Research Council of Turkey (Project No: TOVAG 104O199).

\section{References}

Aka-Kacar Y \& Cetiner S (1992). The changes observed during the micropropagation of strawberry cultivars by meristem culture. In: Proceedings of II. National Horticulture Congress, Adana, Turkey pp. 351-355

Alcantara E, Romera F J, Canete M \& de la Guardia M D (2000). Effects of bicarbonate and iron supply on Fe(III) reducing capacity of roots and leaf chlorosis of $\mathrm{Fe}$ susceptible peach rootstock 'Nemaguard'. Journal of Plant Nutrition 23: 1607-1617. https://doi.org/10.1080/01904160009382127

Alkan Torun A, Serce S, Aka Kacar Y \& Erdem N (2013). Screening of wild strawberry genotypes against iron deficiency under greenhouse conditions. Notulae Botanicae Horti Agrobotanici Cluj-Napoca 41: 560-566. https://doi.org/10.15835/nbha4129111

Alkan Torun A, Aka Kacar Y, Bicen B, Erdem N \& Serce S (2014). In vitro screening of octoploid Fragaria chiloensis and Fragaria virginiana genotypes against iron deficiency. Turkish Journal of Agriculture and Forestry 38: 167-179. https://doi.org/10.3906/tar-1305-83

Álvarez-Fernández, A, Abadía J \& Abadía A (2006). Iron deficiency, fruit yield and fruit quality. In: Bartonand L L, Abadia J, editors. Iron Nutrition in Plants and Rizospheric Microorganisms. The Netherlands, Springer pp. 437-448. https://doi.org/10.1007/1-4020-4743-6_4

Álvarez-Fernández A, Melgar J C, Abadía J \& Abadía A (2011). Effects of moderate and severe iron deficiency chlorosis on fruit yield, appearance and composition in pear (Pyrus communis L.) and peach (Prunus persica (L.) Batsch). Environmental and Experimental Botany 71: 280-286. https://doi.org/10.1016/j.envexpbot.2010.12.012

Awad F, Romheld V \& Marschner H (1994). Effect of root exudates on mobilization in the rhizosphere and uptake of iron by wheat plants. Plant and Soil 165: 213-218. https://doi.org/10.1007/bf00008064

Cakmak I, van de Wetering D A, Marschner H \& Bienfait H F (1987). Involvement of superoxide radical in extracellular ferric reduction by iron-deficient bean roots. Plant Physiology 85(1): 310-314. https://doi.org/10.1104/pp.85.1.310

Camp S D, Jolley V D \& Brown J C (1987). Comparative Evaluation of Factors Involved in Iron-Stress Response in Tomatoes and Soybean. Journal of Plant Nutrition 10: 423-442. https://doi.org/10.1080/01904168709363583

Chen J, Shang Y T, Zhang N N, Zhong Y Q W \& Wang W H (2018). Sodium hydrosulfide modifies the nutrient ratios of soybean (Glycine $\max$ ) under iron deficiency. Journal of Plant Nutrition and Soil Science 181: 305-315. https://doi.org/10.1002/jpln.201700262

Eyupoglu F (1999). Fertility levels of Turkish soils. R.T. Prime Ministry, General Directorate of Rural Affairs.

Gama F, Saavedra T, da Silva J P, Miguel M G \& de Varennes A (2016). The memory of iron stress in strawberry plants. Plant Physiology and Biochemistry 104: 36-44. https://doi.org/10.1016/j.plaphy.2016.03.019

Gundogdu M, Berk S K, Yildiz K, Canan I, Ercisli S \& Tuna S (2020). Effect of methyl jasmonate application on bioactive contents and agromorphological properties of strawberry fruits. Acta Sci. Pol. Hortorum Cultus 19(4): 133-142. https://doi.org/10.24326/asphc.2020.4.12

Han Z H, Shen T, Korcak R \& Baligar V C (1994). Screening for iron-efficient species in the genus Malus. Journal of Plant Nutrition 17: 579592. https://doi.org/10.1080/01904169409364751

Han Z H, Shen T, Korcak R \& Baligar V C (1998). Iron absorption by iron-efficient and - inefficient species of apples. Journal of Plant Nutrition 21: 181-190. https://doi.org/10.1080/01904169809365392

Hancock J F, Callow P W, Dale A, Luby J J \& Finn C E (2001a). From the Andes to the Rockies: Native strawberry collection and utilization HortScience 36: 221-225. https://doi.org/10.21273/hortsci.36.2.221

Hancock J F, Callow P W, Serçe S \& Schilder A M C (2001b). Relative performance of strawberry cultivars and native hybrids on fumigated and nonfumigated soil in Michigan. HortScience 36: 136-138. https://doi.org/10.21273/hortsci.36.1.136

Hancock J F, Finn C A, Hokanson S C, Luby J J, Gourant B L \& Demchak K (2001c). A multi-state comparison of native octoploid strawberries from North and South America. Journal of the American Society for Horticultural Science 126: 579-586. https://doi.org/10.21273/jashs.126.5.579

Hancock J F, Luby J J, Dale A, Callow P W, Serçe S \& El-Shiek A (2002). Utilizing wild Fragaria virginiana in strawberry cultivar development: inheritance of photoperiod sensitivity, fruit size, gender, female fertility and disease resistance. Euphytica 126: 174-184. https://doi.org/10.1007/s10681-007-9575-3

Hancock J F, Callow P W, Serçe S \& Son P Q (2003). Variation in the horticultural characteristics of native Fragaria virginiana and $F$ chiloensis from North and South America. Journal of the American Society for Horticultural Science 128: 201-208. https://doi.org/10.21273/jashs.128.2.0201

Hancock J F, Serçe S, Portman C M, Callow P W \& Luby J J (2004). Taxonomic variation among North and South American subspecies of Fragaria virginiana Miller and F. chiloensis (L) Miller. Canadian Journal of Botany 82(11): 1632-1644. https://doi.org/10.1139/b04-113

Hancock JF, Drake CA, Callow PW \& Serçe S (2005). Genetic improvement of the Chilean native strawberry, Fragaria chiloensis. HortScience 40: 1644-1645. https://doi.org/10.21273/hortsci.40.6.1644

Hancock J, Finn C E, Luby J J, Dale A, Callow P W \& Serçe S (2010). Reconstruction of the strawberry, Fragaria $\times$ ananassa, using native genotypes of $F$. virginiana and $F$. chiloensis. HortScience 45: 1006-1013. https://doi.org/10.21273/hortsci.45.7.1006

Hansen N C, Hopkins B G, Ellsworth J W, Jolley V D, Barton L L \& Abadia J (2006). Iron nutrition in field crops. Iron nutrition in plants and rhizospheric Microorganisms. The Netherlands: Springer pp. 23-59. https://doi.org/10.1007/1-4020-4743-6_2 
Jelali N, Dell'Orto M, Rabhi M, Zocchi G, Abdelly C \& Gharsalli M (2010). Physiological and biochemical responses for two cultivars of Pisum sativum ("Merveille de Kelvedon" and "Lincoln") to iron deficiency conditions. Scientia Horticulturae 124: 116-121. https://doi.org/10.1016/j.scienta.2009.12.010

Kafkas E, Silberbush M \& Paydas S (2007). Physiological characterization of strawberry cultivars with differential susceptibility iron deficiency. World Journal of Agricultural Sciences 3: 196-203.

Lewers K S, Turechek W W, Hokanson S C, Maas J L \& Hancock J F (2007). Evaluation of elite native strawberry germplasm for resistance to anthracnose crown rot disease caused by Colletotrichum species. Journal of the American Society for Horticultural Science 132: 842849. https://doi.org/10.21273/jashs.132.6.842

Lichtenthaler H K \& Wellburn A R (1983). Determinations of total carotenoids and chlorophylls a and b of leaf extracts in different solvents. Biochemical Society Transactions 11(5): 591-592. https://doi.org/10.1042/bst0110591

Luby J J, Hancock J F, Dale A \& Serçe S (2008). Reconstructing Fragaria $\times$ ananassa utilizing wild F. virginiana and F. chiloensis: Inheritance of winter injury, photoperiod sensitivity, fruit size, gender, female fertility and disease resistance in hybrid progenies. Euphytica 163: 57 65. https://doi.org/10.1007/s10681-007-9575-3

Marschner H (2011). Marschner's Mineral Nutrition of Higher Plants, $3^{\text {rd }}$ Edn, London: Academic Press

Mengel K \& Malissovas N (1982). Light depended proton excretion by roots of entire vine plants (Vitis vinifera L.). Z Pflanzenernaeh Bodenk 145:261-267. https://doi.org/10.1002/jpln.19821450306

Murashige T \& Skoog F A (1962). Revised medium for rapid growth and bioassays with tobacco tissue cultures. Physiologia Plantarum 15:473497. https://doi.org/10.1111/j.1399-3054.1962.tb08052.x

Ollat N, Tandonnet J P, Lafontaine M \& Schultz H R (2003). Short and long term effects of three rootstocks on Cabernet Sauvignon vine behaviour and wine quality. Acta Horticulturae 617: 95-99. https://doi.org/10.17660/actahortic.2003.617.13

Ozturk L, Yazici M A, Yucel C, Torun A, Cekic C \& Bagci A (2006). Concentration and localization of zinc during seed development and germination in wheat. Physiologia Plantarum, 128: 144-152. https://doi.org/10.1111/j.1399-3054.2006.00737.x

Pastor M, Castro J \& Hidalgo J (2002). La correzione della clorosi ferrica dell'olivo. Olivae 90: 42-45

Pestana M, Domingos I, Gama F, Dandlen S A, Miguel M G \& Pinto J C (2011) Strawberry recovers from iron chlorosis after foliar application of a grass-clipping extract. Journal of Soil Science and Plant Nutrition 174: 473-479. https://doi.org/10.1002/jpln.201000215

Pestana M, Gama F, Saavedra T, de Varennes A \& Correia P J (2012a). The root ferric-chelate reductase of Ceratonia siliqua (L.) and Poncirus trifoliata (L.) Raf. responds differently to a low level of iron. Scientia Horticulturae 135: 65-67. https://doi.org/10.1016/j.scienta.2011.12.018

Pestana M, Correia P J, Saavedra T, Gama F, Abadia A \& de Varennes A (2012b). Development and recovery of iron deficiency by iron resupply to roots or leaves of strawberry plants. Plant Physiology and Biochemistry 53: 1-5. https://doi.org/10.1016/j.plaphy.2012.01.001

Rombola A D \& Tagliavini M (2006). Iron nutrition of fruit tree crops. In: Barton LL, Abadía J (editors). Iron nutrition in Plants and Rhizospheric Microorganisms. The Netherlands: Springer pp. 61-83. https://doi.org/10.1007/1-4020-4743-6_3

Sanz M, Cavero J \& Abadia J (1992). Iron chlorosis in the Ebro River basin, Spain. Journal of Plant Nutrition 15:1971-1981. https://doi.org/10.1080/01904169209364451

Serce S \& Hancock J F (2002). Screening of strawberry germplasm for resistance to the two-spotted spider mite. Horticultural Science 37: 593-594. https://doi.org/10.21273/hortsci.37.3.593

Serce S \& Hancock J F (2005). The temperature and photoperiod regulation of flowering in Fragaria chiloensis, F. virginiana, and $F$. $\times$ ananassa genotypes. Scientia Horticulturae 103: 167-177. https://doi.org/10.1016/j.scienta.2004.04.017

Serce S, Callow P W, Ho H \& Hancock J F (2002). High temperature effects on $\mathrm{CO}_{2}$ assimilation rate in genotypes of Fragaria $\times$ ananassa F. chiloensis and F. virginiana. Journal of the American Pomological Society 56: 57-62

Tagliavini M, Rombola A D \& Marangoni B (1995). Responses to the iron-deficiency stress of pear and quince genotypes. Journal of Plant Nutrition 18: 2465-2482. https://doi.org/10.1080/01904169509365077

Tagliavini M \& Rombola A D (2001). Iron deficiency and chlorosis in orchard and vineyard ecosystems. European Journal of Agronomy 15: 71-92. https://doi.org/10.1016/s1161-0301(01)00125-3

Tagliavini M, Abadia J, Rombola A, Abadia A, Tsipouridis C \& Marangoni B (2000). Agronomic means for the control of iron deficiency chlorosis in deciduous fruit trees. Journal of Plant Nutrition 23:11-12. https://doi.org/10.1080/01904160009382161

Takkar P N \& Kaur N P (1984). HCl method for Fe+2 estimation to resolve iron chlorosis in plants. Journal of Plant Nutrition 7(1-5): 81-90. https://doi.org/10.1080/01904168409363176

Vizzotto G, Pinton R, Bomben C, Cesco S, Varanini Z \& Costa G (1999). Iron reduction in iron-stressed plants of Actinidia deliciosa genotypes: Involvement of $\mathrm{PM} \mathrm{Fe}(\mathrm{III})$-chelate reductase and $\mathrm{H}+$-ATPase activity. Journal of Plant Nutrition 22: 479-488. https://doi.org/10.1080/01904169909365645

Vose P B (1982). Iron nutrition in plants: A world overview. Journal of Plant Nutrition 5: 233-249

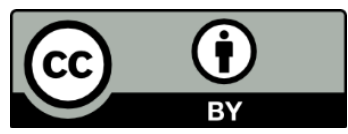

(C) 2022 by the author(s). Published by Ankara University, Faculty of Agriculture, Ankara, Turkey. This is an Open Access article distributed under the terms and conditions of the Creative Commons Attribution (CC BY) license (http://creativecommons.org/licenses/by/4.0/), which permits unrestricted use, distribution, and reproduction in any medium, provided the original work is properly cited. 